\title{
Proposing Stewardship Theory as an Alternate to Explain the Relationship between CSR and Employees' Pro-Environmental Behavior
}

\author{
Shah Ali Murtaza ${ }^{1}\left(\mathbb{D}\right.$, , Asif Mahmood ${ }^{2, *(\mathbb{D})}$, Saima Saleem ${ }^{3}$, Naveed Ahmad ${ }^{4}\left(\mathbb{D}\right.$, Muhammad Suhail Sharif $^{5}$ \\ and Edina Molnár 1,*(D) \\ 1 Institute of Management and Organizational Sciences, University of Debrecen, 4032 Debrecen, Hungary; \\ shah.ali.murtaza@econ.unideb.hu \\ 2 Department of Business Studies, Namal Institute, Mianwali 42250, Pakistan \\ 3 Institute of Quality \& Technology Management, University of the Punjab, Lahore 54590, Pakistan; \\ saima.iqtm@pu.edu.pk \\ 4 Faculty of Management Studies, University of Central Punjab, Lahore 54000, Pakistan; \\ naveeddgk2010@gmail.com \\ 5 Institute of Business Management and Administrative Sciences, The Islamia University of Bahawalpur, \\ Bahawalpur 63100, Pakistan; suhail.sharif@iub.edu.pk \\ * Correspondence: asif.mahmood@namal.edu.pk (A.M.); molnar.edina.phd@econ.unideb.hu (E.M.)
}

check for updates

Citation: Murtaza, S.A.; Mahmood, A.; Saleem, S.; Ahmad, N.; Sharif, M.S.; Molnár, E. Proposing Stewardship Theory as an Alternate to Explain the Relationship between CSR and Employees' Pro-

Environmental Behavior Sustainability 2021, 13, 8558. https:// doi.org/10.3390/su13158558

Academic Editors: Valentín Molina-Moreno, Juan Victor Meseguer Sánchez and Gabriel López-Martínez

Received: 3 July 2021

Accepted: 29 July 2021

Published: 31 July 2021

Publisher's Note: MDPI stays neutral with regard to jurisdictional claims in published maps and institutional affiliations.

Copyright: (c) 2021 by the authors. Licensee MDPI, Basel, Switzerland. This article is an open access article distributed under the terms and conditions of the Creative Commons Attribution (CC BY) license (https:/ / creativecommons.org/licenses/by/ $4.0 /)$.

\begin{abstract}
The aim of the current analysis is to test the relationship between corporate social responsibility (CSR) and employee's pro-environmental behavior (E-PEB) with the mediating effect of servant leadership (SL). The data of the current study were collected from banking employees ( $n=392)$ serving in different banks of Pakistan through a self-administered (paper-pencil method) questionnaire and analyzed by employing structural equation modeling (SEM). The empirical results revealed that CSR directly influences E-PEB; however, this relationship is better explained in the presence of SL as a mediator (mediation explained 35\% variation in E-PEB). The findings of this analysis will help academia and the banking industry improve their understanding of CSR to shape employees' environment-specific behavior. Further, these findings will also help to deal with climate change by engaging the bank employees in different environment-specific activities to improve the overall environmental footprint of a bank.
\end{abstract}

Keywords: corporate social responsibility; pro-environmental behavior; servant leadership; bank; extra-role behavior

\section{Introduction}

The vulnerable climatic conditions in different regions of the world have raised the concern about the environment among all stakeholders [1]. Environmental issues such as extreme weather, depletion of the ozone layer, and scarcity of natural resources, including clean water and compromised ecosystems, are some of the related examples that give rise to the concern for the environment at all levels [1,2]. In this regard, the striking observation is that businesses around the world have significantly contributed directly or indirectly to the current state of environmental vulnerability [3]. Realizing this fact, corporations all over the world are showing their seriousness in improving their environmental footprints. Contemporary businesses around the globe are attempting to find ways that can improve their environmental performance. Perhaps this is the reason that the recent literature has significantly acknowledged the importance of employees of an organization to enhance its environmental performance [4,5]. Thus, the current surge in literature towards employees' pro-environmental behavior (E-PEB) is not without logic. The literature has shown that E-PEB not only improves organizational efforts to preserve the environment [6-8] but also supports its economic objectives. Many large organizations in the contemporary 
business world are engaging their employees in different tasks to preserve nature and the environment.

Owing to the benefits of E-PEB, contemporary scholars have paid considerable attention to explore the factors that can influence employees' behavior towards the environment. In this regard, a stream of researchers has argued that individual factors such as subjective norms, motivation, and individual commitment can influence E-PEB at the workplace [9-11]. Similarly, another stream of research has also acknowledged the importance of organizational factors in shaping employees' environment-specific behavior [12,13]. However, the concern among researchers to explain E-PEB is growing, and no consensus has been made to what is the exact set of factors that an organization needs to equip itself to shape the pro-environmental behavior of its employees.

It is quite recently that scholars have found that corporate social responsibility (CSR) efforts of an organization can shape the extra-role behavior of employees, especially E-PEB. However, this relationship between CSR and E-PEB is still in the formation stage, implying that there is a need to conduct more research in this area. Therefore, one core objective of this research study is to explore the relationship between CSR and E-PEB.

The role of leadership is also important to engage the employees in certain extra roles [14,15]. Organizations can craft better strategies, but this is no guarantee that these better strategies can bring required outcomes without the intervention of proper leadership. The role of leadership in shaping employees' behavior is acknowledged by several scholars $[16,17]$. Specifically, the role of servant leadership (SL) to explain employees extra-role behavior is a phenomenon that recently emerged in the literature [18]. As an instance, Afsar et al. [19] posited that SL serves as a potential mediator to explain the pro-environmental behavior of employees. Thus, another objective of the current research is to investigate the mediating effect of SL between the relationship of CSR and E-PEB.

The current study selected the banking sector of Pakistan to test the proposed relationship. The banking sector of Pakistan is one of the leading service sectors of the country, which operates almost in every corner of the country. Further, this sector is a labor-intensive sector, thus observing the environment-specific behavior of the employees is quite relevant. Furthermore, the banking sector of Pakistan is a service sector in which an established CSR framework exists.

The current study offers several important contributions to the available literature. For example, it is one of those few studies which considers CSR from the standpoint of employees, as the larger focus of the previous studies in the domain of CSR remain to achieve organization-wide economic performance [20-22], organizational efficiency [23,24], and organizational reputation [25]. Similarly, the current study adds to the available literature of the CSR-environment relationship from the perspective of the banking sector (service industry). In this regard, the previous studies largely considered manufacturing sectors because manufacturing industries significantly add to environmental pollution [26]. Although this argument is genuine, that the manufacturing sector is pollution-emitting, this does not imply that the service sector is an exception for this matter, as the involvement of the service sector to improve the natural environment is also important. Lastly, the current study adds to the existing literature of CSR and E-PEB by introducing SL as a potential mediator. Though the relevance of SL is acknowledged in the available literature, studies in this area are still sparse. The remainder of this article is composed of four major parts, including literature review, methodology, results, and discussion. The coming paragraphs deal with these sections in detail for the readers.

\section{Literature and Hypotheses Development}

This study is grounded in the philosophy of stewardship theory to explain the proposed relationships and to state hypotheses. This theory was proposed by Donaldson and Davis [27] and it argues that "individuals, as stewards, are assumed to be intrinsically motivated to work for others or organizations in order to complete various tasks for which they were entrusted". Further, this theory is in agreement that stewards have a 
collectivistic approach, and hence they are pro-organizational, unlike the individualistic approach in which individuals are assumed to be self-centered. Thus, a steward attempts to work to keep the greater benefit of the organization and society to the fore. Scholars have significantly considered this theory as a framework that specifies the motivations for an individual's behavior $[28,29]$. In an organizational context, stewards are expected to demonstrate a caring attitude to the future of their organization [30].

The notion of stewardship joins the lexicon of CSR and servant leadership significantly as both CSR and SL stress upon the "shared responsibility" to take care of all stakeholders [31]. Specifically, the notion of environmental stewardship is something that is closely related to CSR. Following environmental stewardship, a socially responsible organization assumes the responsibility to carefully manage the resources so that they can be passed on to future generations [32]. Thus, as a follower of stewardship theory, a socially responsible organization not only works for the betterment of the employees and society, but it also takes those initiatives for which it was not responsible for taking any action to protect the environment. The difference between a conventional socially responsible organization and the one that follows the stewardship concept is that a traditional socially responsible organization generally follows the stakeholder theory concept, in which an organization is assumed to be more instrumental in taking care of organizational stakeholders. In other words, the socially responsible organization under the philosophy of stakeholder theory is expected to work for the betterment of those stakeholders who are related to the organization. However, a socially responsible organization that follows the philosophy of stewardship theory takes a different position as its approach is covenantal. It employs the concept of "care for others" at a further level by broadening its concern for society and the environment beyond the fiduciary obligations [33].

CSR perception of employees serving in an organization infuses the sense of caring for others among the employees, and they are expected to support their organization to achieve its CSR objectives by participating in different activities to preserve the environment [34]. This environment-specific behavior is termed E-PEB, which is defined in an organizational context as "the behavior of an employee to reduce the negative impact on the built environment through his or her actions at the workplace" [35]. This includes employees printing on both sides of the paper or not printing unnecessary documents, using stairs instead of electronic escalators, turning unnecessary lights off, etc. In this regard, employees serving in a socially responsible organization develop this sense that their organization is a caring organization and has a seriousness for the greater good of others. Further, employees also observe that their organization participates in different extra tasks that were not formally required to be observed by any state law; rather, their organization is actuating those extra tasks in the greater interest of society and the environment. Therefore, the relevant observation is that employees serving in such organizations are convinced to adopt such discretionary practices on their own. Thus, they engage themselves in different environment-friendly tasks. The links between employee CSR perceptions and their pro-environmental behavior is established in the recent available literature. In this respect, Raza et al. [36] posited that the CSR perception of employees could positively predict their pro-environmental behavior in the context of the hotel sector. Moreover, Islam et al. [37] produced the same line of argument in the context of the hospitality sector of Paris. More recently, Ahmad et al. [38] appeared with the findings that E-PEB is an outcome of an organization's CSR engagement. Various other scholars have also produced this striking observation that CSR is a potential enabler to keep the employees engaged in different discretionary behaviors. The studies of Abdelmotaleb et al. [39], Chaudhary and Akhouri [40], Yu et al. [41], and Afsar and Umrani [42] are some of the recent examples in this context. In sum, in line with stewardship theory, an organization's CSR activities are well received by its employees, and it infuses among the employees that like their organization, that they are also stewards to preserve nature for future generations. Thus, they become more self-responsible and are expected to be more engaged in E-PEB. Thus, the following hypothesis is framed: 
Hypothesis 1 (H1). Employees' CSR perception about their organization is positively related to their pro-environmental behavior.

Similarly, the stewardship theory is a close fit to the concept of SL. In line with this theory, the authors argue here that servant leaders put their self-interest behind the organizational interests to produce the greater good for all. Moreover, a servant leader is one who believes in the philosophy to serve others as contrasted by the traditional style of leadership that focuses on the strategies that thrive in the interest of shareholders [43]. A servant leader is a believer of stewardship theory and has developed such policies for employees that produce greater good for all. Stewardship theory, therefore, helps to understand the underlying mechanism of psychological factors that shape specific behavior of individuals, especially their discretionary behaviors [44]. Servant leaders support and help their employees to achieve different objectives. Basically, a servant leader attempts to infuse this among employees that every employee is a servant-employee who is assumed to serve for the greater good of the organization, society, and the environment [45]. In fact, a servant leader who follows the stewardship concept is expected to inculcate the sense of caring among employees even at a higher level as they infuse among the employees that they need to think and act as stewards. They are encouraged to work for the greater good of the organization and society, despite the fact that one task is officially required or not [46]. More specifically, a servant leader under the philosophy of stewardship has a normative standpoint in building social relations and taking steps to preserve the environment [47]. In this context, a servant leader also transmits this normative standpoint to take care of the organizational assets for the future. The available literature has considerably considered the role of SL in shaping the pro-environmental behavior of employees $[46,48]$.

Organizations craft different strategies, but in order to enable these strategies to be well implemented, the organization needs corporate leaders. In other words, leaders work as a bridge between organizations and employees. An organization may craft better CSR strategies, but leadership intervention is a prerequisite to receive an effective response for such strategies from employees. Different scholars have argued that in the presence of effective leadership, the likelihood for an organization to achieve its objective is high $[49,50]$.

In the context of the current study, a servant leader helps the workers clearly understand an organization's CSR approach to preserve the natural resources and the environment. Moreover, a servant leader clarifies to every worker that their contribution to improving an organization's environmental footprint is very important. Generally, it is established in the literature that in the presence of effective leadership, the relationship between CSR and employees' behavior is better explained [19,51]. To conclude, an organization's CSR engagement is an enabler to positively influence E-PEB; however, the presence of a servant leader explains this relationship in a clearer way. Thus, the following set of hypotheses is framed.

Hypothesis 2 (H2). Servant leadership is positively related to E-PEB.

Hypothesis 3 (H3). Servant leadership mediates between CSR and E-PEB.

\section{Methods}

The target sector to test the proposed relationships (Figure 1) for the current study is the banking sector of Pakistan. The authors feel this sector is relevant to the current analysis due to two specific reasons. First, the banking sector of Pakistan, like in other regions of the world, is highly competitive and requires extra efforts from every player to keep itself alive in the business. The fact aggravates the situation that the banking sector is highly homogenized in which all players have to follow a standard procedure. Thus, very little is left for a player to differentiate itself from the rest of the crowd to induce its performance. In this regard, the authors argue here that E-PEB, on the one hand, helps a bank to reduce its environmental footprint; on the other hand, it also induces a bank's 
overall performance [52]. The authors' argument lies in the logic that when employees of a bank show pro-environmental behavior, it means they do not waste resources, and thus this efficient use of resources is something that can bring extra benefit for a bank. Second, though this sector is not assumed to be a pollution-spreading sector, unlike the manufacturing industries, this sector's indirect effect on the environment is enormous [53,54]. This argument lies in the fact that the banking sector is one of the largest service sectors of the country and employs a huge workforce that operates in every city of Pakistan, and if the pro-environmental behavior of the employees in this sector is improved, then it can help Pakistan to address the vulnerable climatic conditions in the country [55].

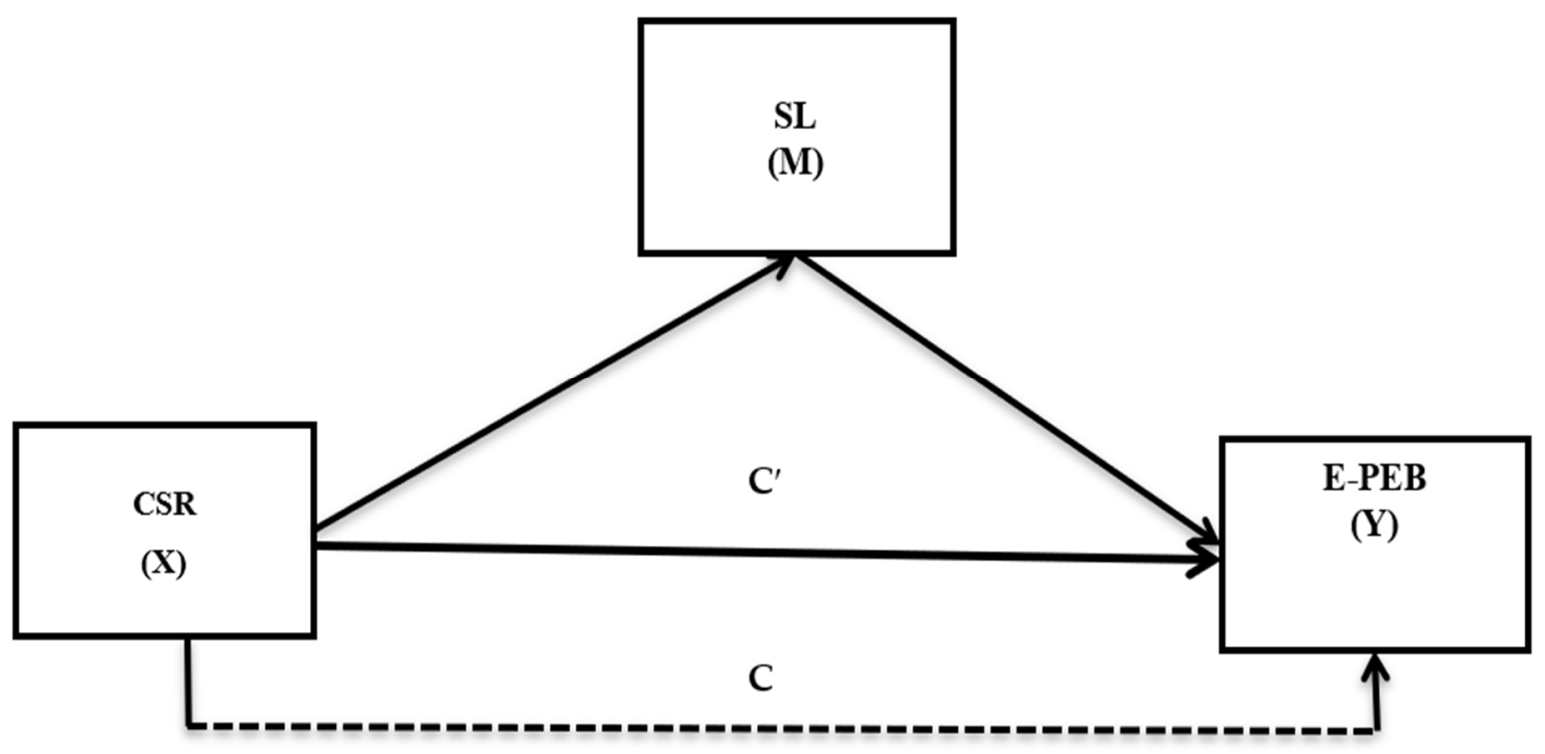

Figure 1. The proposed research model: CSR is a predictor that is represented by X, SL is the intervening variable represented by $\mathrm{M}$, and E-PEB is the criterion variable described by $\mathrm{Y}$.

The banking sector of Pakistan is characterized by two major banking systems, conventional banking and Islamic banking. However, the Islamic banking system is still evolving in the country as the industry is dominated by the conventional banking system, which constitutes almost $84 \%$ of the total banking industry [56]. To represent the banking sector, the authors included five large banks in the country, such as Habib Bank Limited (HBL), Allied Bank Limited (ABL), United Bank Limited (UBL), National Bank of Pakistan (NBP), and MCB Bank Limited. The selection of these banks was made due to two reasons. Firstly, all of these selected banks are the major players in the industry and capture more than $50 \%$ of the industry's share [57]. Further, these banks maintain their presence in every city of the country. Secondly, all of these banks were practicing different CSR activities. The authors validated this engagement through paying personal visits to these banks and by visiting their web pages. In this regard, all of these banks have a separate webpage related to CSR activities [58-61].

To collect the data from these banks, the authors selected Lahore city of Pakistan, the capital of Punjab province. The rationale for selecting this city lies in the fact that Lahore city is a city with a multi-million population, reported as one of the most polluted cities in the world [62]. The second reason for selecting Lahore is that the data for the current project were collected during the COVID-19 pandemic, due to which movement in different cities was restricted. Thus, the authors had a limited choice in this regard.

Before proceeding with the formal data collection stage, the authors formally contacted the concerned banking officials to seek their permission to collect the data from their employees. After receiving this formal permission, the authors then arranged for the dates and timings to collect the data from banking employees. It is to be mentioned here that the third wave of COVID-19 in the country posed some severe challenges for authors during 
the data collection stage. For example, the authors had to main a safe social distance while entering a bank, and the authors were not allowed to meet more than ten participants at one time for data collection. Such safety measures made the data collection process challenging as the authors had to stay in a bank for extra hours with repeated visits. The activity of the data collection process was completed in a month (March-April, 2021).

A printed version of the questionnaire was served to collect the data from the respondents. In this regard, the current study observed the ethical protocols of the Helsinki Declaration in order to maintain the highest ethical standards. The respondents were served with a separate sheet to obtain their "informed consent". This sheet was attached with each questionnaire for the convenience of participants. Moreover, the participants of the current survey were given every choice to quit the data filling process at any stage if they felt uncomfortable in sharing the information. Initially, the authors distributed 600 questionnaires among the employees of different banks. The authors were able to receive 392 filled questionnaires, which established a response rate of almost $65 \%$. The questionnaire was divided into two major parts. The first part of the questionnaire was specific to the demographic information of the respondents (Table 1) and the second part was pertinent to the information of study variables. To further assist in the sampling process, the authors requested the competent authority of each bank to randomly indicate the concerned staff, including both managers/supervisors and the employees. Once this random selection was made, in most cases, the staff were invited to the meeting room of a bank, where a 50\% seating arrangement was made to maintain a safe social distance due to the COVID-19 pandemic.

Table 1. Demographic detail.

\begin{tabular}{ccc}
\hline Demographics & Frequency $(\boldsymbol{n}=\mathbf{3 9 2})$ & $\%$ \\
\hline Gender & & \\
Male & 223 & 56.89 \\
Female & 169 & 43.11 \\
Age group (Years) & & \\
$22-25$ & 49 & 12.50 \\
$26-30$ & 103 & 26.02 \\
$31-35$ & 96 & 24.49 \\
$36-40$ & 87 & 22.19 \\
Above 40 & 57 & 14.54 \\
Experience (Years) & 79 & 20.15 \\
$1-4$ & 128 & 32.65 \\
$5-7$ & 98 & 25.01 \\
$8-10$ & 87 & 22.19 \\
Above 10 & & 31.63 \\
Category & 124 & 68.37 \\
Manager & 268 & 100 \\
Non-Manager & 392 & \\
Total & &
\end{tabular}

Measures and Addressing the Issue of Social Desirability

The current study employed already established scales from different reliable sources. One of the major advantages of using already available scales is that their validity and reliability are pre-established [63]. The authors adapted the CSR scale from the study of Turker [64]. Various scholars have widely used this scale to measure the CSR perception of employees. For example, Raza, Farrukh, Iqbal, Farhan and Wu [36] used this scale to measure employees' CSR perception in Pakistan's hotel sector. Whereas, in their recent study, Tian and Robertson [65] used this scale to measure CSR perception of employees in the large and medium casino industry of China. This scale comprised 12 items, among which a sample item was "Our bank participates in activities, which aim to protect and improve the quality of the natural environment". The scale of servant leadership was adapted from the study of Liden et al. [66], which constituted seven items. A sample item 
was "My leader would not compromise ethical principles in order to achieve success". This scale is a famous scale that various scholars use to measure SL. For example, in a recent study Opoku et al. [67] used this scale to measure SL in the manufacturing sector of Ghana. Moreover, Afsar, Cheema and Javed [19] used this scale to measure SL in various sectors of Pakistan. Lastly, the scale of pro-environmental behavior was employed from the study of Mithani [68], which is a well-known scale to measure the construct of pro-environmental behavior. Previous researchers such as NBP [58] used this scale in the healthcare sector of Pakistan, and Afsar, Cheema and Javed [19] used this scale in various industrial sectors. This scale comprised 7 items, among which a sample item was "I turn lights off when not in use". The authors used a five-point Likert scale to record the ratings of respondents. Table 1 represents the demographic details of the participants.

\section{Results}

\subsection{Common Method Variance}

The current study collected the information of all variables from the same participant at a specific point in time which gave rise to the concern of the presence of common method variance (CMV), which may lead to false internal consistency [69]. Thus, the authors decided to test whether the potential issue of CMV requires any correcting action or not. In doing so, the authors employed Harman's single-factor test and loaded all the items in the questionnaire (only the items of variables) on a single factor. The standard practice in this respect is that if the outcome of a single factor test indicates that the strong single factor explains a variation of $50 \%$ or more, the presence of CMV is confirmed, and needs to be addressed by the authors before proceeding further in the stage of data analysis. However, in the current case, the results of the single-factor test revealed no such issue as the single dominating factor was explaining only $31.89 \%$ of the total variance. Moreover, the authors also employed a single confirmatory factor analysis (CFA) and loaded all the items on a single factor. In this regard, the results of the CFA for the one-factor model revealed a poor fit $\left(\chi^{2}=2781.626, d f=386, \chi^{2} / d f=7.21\right.$, RMSEA $\left.=0.096, \mathrm{CFI}=0.55, \mathrm{NFI}=0.61\right)$. These results once again established that CMV is not a potential issue in the current dataset and requires no further action.

\subsection{Factor Loadings, Validity, and Reliability}

The satisfactory results of CMV paved the way for the authors to continue with the data analysis stage. The authors then calculated average variance extracted (AVE) to verify if the majority of the variation was explained by the variable or the error term. As indicated by Fornell and Larcker [70], AVE for a variable is significant if the majority of the shared variation, such as $50 \%$ or beyond, is explained by the variable under investigation. The authors used the following formula to calculate AVE for each variable.

$$
\text { Average variance extracted }=\frac{\sum_{i=i}^{k} \lambda_{i}^{2}}{\sum_{i=i}^{k} \lambda_{i}^{2}+\sum_{i=1}^{k} \operatorname{var}\left(\varepsilon_{i}\right)}
$$

For calculating AVE, the factor loadings (Table 2) of each item of a variable were used to be incorporated in the above formula. The authors performed factor analysis (FA) to achieve factor loadings. The results of FA produced significant results for all items $(\lambda>0.5)$. However, one item of E-PEB (E-PEB3) did not produce good factor loading as its loading was 0.39 , which was well below the standard criterion of $\lambda>0.5$. Therefore, this item was not considered in any further analysis, and thus, a total of six items were retained to operationalize E-PEB. The FA was conducted using principal component analysis (PCA) through varimax rotation. As it can be noted from Table 2, all the variables produced significant AVE values, which means the convergent validity (CVL) for each variable is established. The authors established these results by following the guidelines of Gefen et al. [71], who proposed that the CVL of a variable is significant if AVE values are more than $50 \%$. 
Table 2. Factor loadings, convergent validity, and composite reliability.

\begin{tabular}{|c|c|c|c|c|c|c|c|}
\hline Item & $\Lambda$ & $\lambda^{2}$ & E-Variance & $\sum \lambda^{2}$ & Items & AVE & CR \\
\hline CSR1 & 0.73 & 0.53 & 0.47 & & & & \\
\hline CSR2 & 0.76 & 0.58 & 0.42 & & & & \\
\hline CSR3 & 0.82 & 0.67 & 0.33 & & & & \\
\hline CSR4 & 0.71 & 0.50 & 0.50 & & & & \\
\hline CSR5 & 0.71 & 0.50 & 0.50 & & & & \\
\hline CSR6 & 0.86 & 0.74 & 0.26 & & & & \\
\hline CSR7 & 0.74 & 0.55 & 0.45 & & & & \\
\hline CSR8 & 0.87 & 0.76 & 0.24 & & & & \\
\hline CSR9 & 0.90 & 0.81 & 0.19 & & & & \\
\hline CSR10 & 0.77 & 0.59 & 0.41 & & & & \\
\hline CSR11 & 0.83 & 0.69 & 0.31 & & & & \\
\hline CSR12 & 0.79 & 0.62 & 0.38 & 7.55 & 12 & 0.63 & 0.95 \\
\hline SL1 & 0.76 & 0.58 & 0.33 & & & & \\
\hline SL2 & 0.78 & 0.61 & 0.42 & & & & \\
\hline SL3 & 0.81 & 0.66 & 0.48 & & & & \\
\hline SL4 & 0.92 & 0.85 & 0.31 & & & & \\
\hline SL5 & 0.89 & 0.79 & 0.36 & & & & \\
\hline SL6 & 0.73 & 0.53 & 0.41 & & & & \\
\hline SL7 & 0.84 & 0.71 & 0.45 & 4.72 & 7 & 0.67 & 0.93 \\
\hline E-PEB1 & 0.86 & 0.74 & 0.26 & & & & \\
\hline E-PEB2 & 0.83 & 0.69 & 0.31 & & & & \\
\hline E-PEB4 & 0.74 & 0.55 & 0.45 & & & & \\
\hline E-PEB5 & 0.77 & 0.59 & 0.41 & & & & \\
\hline E-PEB7 & 0.77 & 0.59 & 0.41 & & & & \\
\hline E-PEB8 & 0.81 & 0.66 & 0.34 & 3.82 & 6 & 0.64 & 0.91 \\
\hline
\end{tabular}

Next, the authors calculated the composite reliability (CR) for all three variables using the given formula.

$$
\text { Composite reliability }=\frac{\left(\sum \lambda_{i}\right)^{2}}{\left(\sum \lambda_{i}\right)^{2}+\sum \operatorname{var}\left(\varepsilon_{i}\right)}
$$

In this regard, the standard practice among contemporary scholars is that if the value of $C R$ for a variable is 0.7 or beyond, then the CR for that variable is significant. As a case, the CR value for the variable CSR is 0.95 , which is well above the threshold level of 0.7.

In the next data analysis stage, the authors performed correlation analysis and discriminant validity (DVL). As per the detail of correlation analysis (Table 3), it can be observed that all values of correlation are positive and significant, which indicates that variables are positively associated, which is in accordance with the statement of hypotheses of the current analysis. As an instance, one can see the value of correlation between CSR and SL is $r=0.53$, which is positive and showing a moderate level of correlation between these two variables. The same is the case with other variables, as is evident from Table 3 . The values of Cronbach alpha are represented by bold diagonals; as a case, the Cronbach alpha value for CSR is 0.92 . The DVL for each variable in the current analysis was assessed based on the values of maximum shared variance (MSV) and average shared variances (ASV). The standard rule to establish DVL for a variable is that both values of MSV and ASV for that variable should be less than the relative AVE value. To further elaborate, the AVE value of CSR is 0.63 , whereas the values of MSV are 0.28 and ASV is 0.25 , respectively. This established that the variables are dissimilar from each other, and thus DVL is established [72]. The authors also calculated model fit indices (MFI) values during CFA to observe if there was good data fit or not. In this regard, the authors tested different MFI values and found that these MFIs were significant $\left(\chi^{2}=4.111 .823, d f=1409, p<0.01\right.$ $\chi^{2} / d f=2.918$, RMSEA $\left.=0.048, \mathrm{CFI}=0.948, \mathrm{NFI}=0.944\right)$. For instance, $\chi^{2} / d f$ was less than the cut-off range of 0.3 , which is desirable. Likewise, both the values of CFI and NFI were 
also significant as both produced values beyond the cut-off criteria of 0.9. Lastly, the value of RMSEA was below the threshold level of 0.06. All these values of MFIs validated the appropriateness of the measurement model.

Table 3. Correlation, discriminant validity, and model fit indices.

\begin{tabular}{cccc}
\hline Construct & CSR & SL & PEB-E \\
\hline CSR & 0.92 & $0.53^{* *}$ & $0.47^{* *}$ \\
SL & & 0.89 & $0.48^{* *}$ \\
PEB-E & & & 0.87 \\
Mean & 4.53 & 4.02 & 3.97 \\
SD & 0.46 & 0.49 & 0.58 \\
MSV & 0.28 & 0.28 & 0.23 \\
ASV & 0.25 & 0.26 & 0.23 \\
\hline
\end{tabular}

$\overline{\mathrm{SD}}=$ standard deviation, ${ }^{* *}=$ significant values of correlation, diagonal values $=$ Cronbach alpha, maximum shared variance $=$ MSV, and average shared variance $=$ ASV.

\subsection{Hypotheses Testing}

Finally, the authors validated the hypotheses of the current analysis through the structural equation modeling (SEM) technique in AMOS software. The SEM is an advancedlevel data analysis technique to deal with mediation analysis. The SEM is considered preferable over the conventional technique of testing mediation effect, as in SEM, one can observe the proposed relations and their effect on the input variable simultaneously as contrasted by the conventional technique in which this feature is not available. Moreover, the bootstrapping method to test the mediation effect is more sophisticated than the Sobel test technique [73-75]. The hypotheses were validated by drawing the structural model in two stages. In this regard, the first stage of the structural model was actuated by drawing the direct effect model in AMOS. At this point, no mediator was involved in the structural model. The authors have reported the results of the direct effect model in Table 4. According to the output of the direct effect structural model, $\mathrm{H} 1$ and $\mathrm{H} 2$ produced significant results as the beta values for $\mathrm{H} 1$ and $\mathrm{H} 2$ were positive and significant $(\beta 1=0.310$, $\beta 2=0.312, p<0.05$ ). Moreover, the upper-limit confidence interval (ULCI) and lower-limit confidence (LLCI) interval did not include a zero value; thus, $\mathrm{H} 1$ and $\mathrm{H} 2$ of the current study were statistically supported. The values of MFIs were also appropriate in this regard $\left(\chi^{2}=4.062 .622, d f=1539, p<0.01 \chi^{2} / d f=2.639\right.$, RMSEA $\left.=0.041, \mathrm{CFI}=0.953, \mathrm{NFI}=0.952\right)$.

Table 4. The results for hypotheses testing (H1, $\mathrm{H} 2)$.

\begin{tabular}{ccccccccc}
\hline Path & Estimates & SE & CR & $\boldsymbol{R}^{\mathbf{2}}$ & $\boldsymbol{p}$-Value & ULCI & LLCI & Decision \\
\hline CSR $\rightarrow$ E-PEB & $(\beta 1) 0.310^{* *}$ & 0.0714 & 4.18 & 0.296 & $* * *$ & 0.328 & 0.263 & Supported \\
SL $\rightarrow$ E-PEB & $(\beta 2) 0.312^{* *}$ & 0.0714 & 4.21 & 0.279 & $* * *$ & 0.288 & 0.226 & Supported \\
\hline
\end{tabular}

$\mathrm{ULCI}=$ upper-limit confidence interval, LLCI $=$ lower-limit confidence interval, ${ }^{* *},{ }^{* * *},=$ significant values.

In the next stage, the authors drew the structural model again in AMOS. This time SL was acknowledged as a mediator in the model (Table 5). The bootstrapping option in AMOS was enabled with a bootstrapping sample of 2000 at this point in time. The results of the mediated structural model confirmed that SL was producing the mediating effect between CSR and E-PEB $(\beta 3=0.165)$. The authors also calculated the portion explained by the mediation effect by using the given formula and found that mediation significantly explains almost $35 \%$ of the total variation in E-PEB.

$$
\text { Proportion of mediation }=\frac{\text { Indirect effect }}{\text { Total effect }}
$$

Based on the above results, it is validated that $\mathrm{H} 3$ of the current analysis is also supported. The MFIs for the mediated model produced even better results as compared to 
the direct effect model $\left(\chi^{2}=38,14.253, d f=1488, p<0.01 \chi^{2} / d f=2.563\right.$, RMSEA $=0.037$, $\mathrm{CFI}=0.962, \mathrm{NFI}=0.957)$.

Table 5. Mediation results for $\mathrm{H} 3$.

\begin{tabular}{cccccccc}
\hline Path & Estimates & SE & Z-Score & $p$-Value & ULCI & LLCI & Decision \\
\hline CSR $\rightarrow$ SL $\rightarrow$ E-PEB & $(\beta 3) 0.165^{* *}$ & 0.028 & 5.89 & $* * *$ & 0.128 & 0.091 & Supported \\
Total effect & 0.475 & & & & & \\
Indirect effect & 0.165 & & & & & \\
Direct effect & 0.310 & & & & & \\
Proportion of mediation & 0.35 & & & & & \\
\hline
\end{tabular}

$\mathrm{ULCI}=$ upper-limit confidence interval, LLCI $=$ lower-limit confidence interval $,{ }^{* *},{ }^{* * *},=$ significant values, $\mathrm{SE}=$ standard error.

\section{Discussion}

The authors carried out this analysis to achieve two research objectives. Firstly, the authors were interested to know whether CSR can positively predict E-PEB in the banking sector of Pakistan. To this end, the statistical outcomes of the current analysis revealed a positive relationship between employees' CSR perception about their bank and their pro-environmental behavior. Thus, the CSR engagement of a bank can shape the extra-role behavior (pro-environmental behavior in the current case) of employees positively. This statement is also supported by various extant scholars in the field of CSR $[37,38,76]$. The relationship of CSR and E-PEB can also be explained with the help of stewardship theory in a way that following the concept of stewardship, an organization assumes its responsibility to take care of the environment beyond its formal obligation. Moreover, a socially responsible organization characterized by stewardship is likely to develop a normative approach to take care of society and the environment. Under this normative orientation, an organization thinks on a broader horizon to better society and the environment. Unlike stakeholder theory, in which an organization considers its social responsibility to benefit the stakeholders, which can affect or be affected by an organization, an organization that follows the stewardship concept serves the community and the environment without thinking that either it will give benefit to the stakeholders close to the organization or not. On the other hand, employees observe this commitment of their organization and are convinced to support their organization by practicing this socially responsible behavior on their own to preserve nature and the environment. Thus, they become more concerned about taking care of the built environment for future generations.

Secondly, the current study also attempted to explore the mediating effect of SL between the relationship of CSR and E-PEB. In this respect, the statistical results established that the role of SL is very important to explain the proposed relationship of CSR and E-PEB. The leaders are strategic enablers for an organization to achieve different organizational objectives, as indicated by various researchers in the field of organizational management [77-80]. In this regard, the authors argue here that a socially responsible organization is better positioned to infuse its CSR philosophy among employees through a servant leader. The employees of most banks perform their jobs in close coordination with their leaders, and thus, they are the direct observer of the behavior of their leader. In the context of the current analysis, when a servant leader acts as a steward at the workplace, the employees are expected to adopt this behavior of their leader. Furthermore, a servant leader as a steward clearly communicates to each worker that their role is very important to achieve the CSR objectives of their bank. A servant leader sets normative standards at the workplace to cultivate an environment-friendly environment. The role of a servant leader in shaping employees' behavior is also acknowledged by various researchers [81,82]. Moreover, the role of SL to influence pro-environmental behavior also receives support from previous literature $[19,46]$. The results of the current analysis also confirmed the importance of SL as a mediating variable to explain the relationship between CSR and E-PEB. 


\subsection{Implications}

The authors believe that the current study significantly contributes to theory and practice. Firstly, the current study adds in the available literature of CSR to shape the extrarole behavior (pro-environmental) of employees. In this regard, the mainstream literature of CSR has largely assumed this variable to enhance organizational outcomes such as organizational performance [83,84], effectiveness [85], commitment [86], etc. However, the link of CSR with employees' behavior, especially with their extra-role behavior, is nascent in the available literature. Secondly, the current study is one of those limited studies which explored the importance of servant leadership as a mediator to explain the relationship between CSR and E-PEB. In this context, the role of a servant leader for employees' behavior is already acknowledged in the available literature [81,82]. However, its link with the pro-environmental behavior of employees is not explored in the current literature. Last but not least, the current study stresses the importance of the service sector to mitigate the level of environmental dilapidation, whereas the majority of the available literature on the current topic considered the manufacturing sector.

The practical implications of the current analysis are also important to be mentioned here. In this regard, the first important implication of the current analysis is that it presents the concept of CSR for the banking sector of Pakistan to shape the behavior of employees towards the environment. This finding has very special importance for this sector in that employees' pro-environmental behavior helps a bank in its CSR initiatives to preserve the environment and improves the economic performance of a bank. The authors' argument is rooted in the logic that when employees of a bank demonstrate positive behavior to preserve the environment, it implies that they will be using organizational resources in an efficient way, which means wastage of resources will be at its minimal level in a bank, and all these processes will improve the overall performance of a bank. Another important takeaway in this regard is that the prevailing CSR practices in the banking sector of Pakistan are pro-philanthropic in nature. For example, the National Bank of Pakistan has been engaged in different philanthropic activities under the umbrella of CSR. The bank has been helping the disabled persons of the community by providing them with wheelchairs.

Similarly, Allied Bank spends its CSR funds on healthcare, community education, and sports activities. However, CSR activities to improve the pro-environmental behavior of employees are something that is not a major focus of this sector. In this context, the findings of the current study will improve the understanding of policymakers that philanthropic activities are just a part of CSR, and the concept of CSR goes far beyond the philanthropic orientation. Another important practical implication of the current study is that it introduces the importance of an appropriate leadership style (servant leader in the current case) to foster employees' environment-specific behavior. To this end, the banking sector of Pakistan in the past had its recognition for a tightly monitored environment in which the role of leadership was bureaucratic. Though things have improved in this aspect over time, the current findings will further cement the importance of a flexible leadership style to enhance the extra-role behavior of employees. Lastly, this analysis will help the banking institutions reduce the level of environmental dilapidation through employees. Timberland, in this regard, can be put as an example here. The organization, through its continuous emphasis on its employees to improve the environment, is now able to bring its level of wastage close to zero through the active participation of the employees. The employees at Timberland are encouraged to support their organization for a better and sustainable future. By the same token, the banking sector of Pakistan can learn from the experience of Timberland to convert their workplace to a "sustainable workplace" to support the government in its effort to reduce environmental dilapidation.

\subsection{Limitations and Directions for the Future}

This analysis also encounters some limitations which pave the way for future researchers in the same field. For example, an important limitation of this analysis lies with the geographic concentration, as the data were collected only from Lahore. The authors 
have already explained their inability to move frequently to other cities due to COVID-19 restrictions. However, for future research, a sample including different cities is suggested. Likewise, the cross-sectional nature of the data also limits the causality of the proposed relations. Thus, for future researchers, it will be more appropriate if they can incorporate longitudinal data. Moreover, this time the authors did not control for the age and education of the respondents; however, future studies including these variables may produce some extended results to better understand the kind of effect that age and education of the sample influence the proposed relationships. Last but not least, this study attempts to explain employees' behavior, especially their extra-role behavior, through CSR and SL. Though the proposed relations (Figure 1) were significant, the authors still feel that human behavior is very complex to understand, and explaining such complexity with the help of two variables may have specific consequences. Therefore, one suggestion for future researchers is to add more variables to the research model of the current study.

Author Contributions: Conceptualization, S.A.M.; Formal analysis, A.M., M.S.S.; Funding acquisition, E.M., S.A.M.; Investigation, N.A.; Methodology, S.S. and E.M.; Project administration, A.M.; Resources, S.S.; Writing—original draft, S.A.M.; Writing—review \& editing, A.M., N.A. and M.S.S. All authors have read and agreed to the published version of the manuscript.

Funding: This research received external funding.

Institutional Review Board Statement: This study was conducted as per the ethical guidelines given in the Helsinki Declaration. The authors obtained approval from the ethical committee of Namal Institute Mianwali: Pakistan, Ref: NML-ERC/2020-029.

Informed Consent Statement: Informed consent was obtained from the respondents of the survey.

Data Availability Statement: The data will be made available on request from the corresponding author.

Acknowledgments: The publication of this study was supported by the EU-funded Hungarian grant EFOP-3.6.3.-VEKOP-16-2017-00007, for the project entitled "From Talent to Young Researchers"Supporting the Career-developing Activities of Researchers in Higher Education.

Conflicts of Interest: The authors declare no conflict of interest.

\section{References}

1. Aprile, M.C.; Fiorillo, D. Water conservation behavior and environmental concerns: Evidence from a representative sample of Italian individuals. J. Clean. Prod. 2017, 159, 119-129. [CrossRef]

2. Sanchez-Sabate, R.; Sabaté, J. Consumer attitudes towards environmental concerns of meat consumption: A systematic review. Int. J. Environ. Res. Public Health 2019, 16, 1220. [CrossRef]

3. Ince, F. International businesses and environmental issues. In Promoting Global Environmental Sustainability and Cooperation; IGI Global: Hershey, PA, USA, 2018; pp. 86-111.

4. Singh, S.K.; Chen, J.; Del Giudice, M.; El-Kassar, A.-N. Environmental ethics, environmental performance, and competitive advantage: Role of environmental training. Technol. Forecast. Soc. Chang. 2019, 146, 203-211. [CrossRef]

5. Roscoe, S.; Subramanian, N.; Jabbour, C.J.; Chong, T. Green human resource management and the enablers of green organisational culture: Enhancing a firm's environmental performance for sustainable development. Bus. Strat. Environ. 2019, 28, 737-749. [CrossRef]

6. Kim, Y.J.; Kim, W.G.; Choi, H.-M.; Phetvaroon, K. The effect of green human resource management on hotel employees eco-friendly behavior and environmental performance. Int. J. Hosp. Manag. 2019, 76, 83-93. [CrossRef]

7. Gilal, F.G.; Ashraf, Z.; Gilal, N.G.; Gilal, R.G.; Channa, N.A. Promoting environmental performance through green human resource management practices in higher education institutions: A moderated mediation model. Corp. Soc. Responsab. Environ. Manag. 2019, 26, 1579-1590. [CrossRef]

8. Anwar, N.; Mahmood, N.H.N.; Yusliza, M.Y.; Ramayah, T.; Faezah, J.N.; Khalid, W. Green Human Resource Management for organisational citizenship behaviour towards the environment and environmental performance on a university campus. J. Clean. Prod. 2020, 256, 120401. [CrossRef]

9. Bissing-Olson, M.J.; Iyer, A.; Fielding, K.S.; Zacher, H. Relationships between daily affect and pro-environmental behavior at work: The moderating role of pro-environmental attitude. J. Org. Behav. 2013, 34, 156-175. [CrossRef]

10. Graves, L.M.; Sarkis, J.; Zhu, Q. How transformational leadership and employee motivation combine to predict employee proenvironmental behaviors in China. J. Environ. Psychol. 2013, 35, 81-91. [CrossRef] 
11. Lu, H.; Zou, J.; Chen, H.; Long, R. Promotion or inhibition? Moral norms, anticipated emotion and employee's pro-environmental behavior. J. Clean. Prod. 2020, 258, 120858. [CrossRef]

12. Paillé, P.; Boiral, O. Pro-environmental behavior at work: Construct validity and determinants. J. Environ. Psychol. 2013, 36, 118-128. [CrossRef]

13. Lamm, E.; Tosti-Kharas, J.; King, C.E. Empowering employee sustainability: Perceived organizational support toward the environment. J. Bus. Ethics 2015, 128, 207-220. [CrossRef]

14. Raub, S.; Robert, C. Differential effects of empowering leadership on in-role and extra-role employee behaviors: Exploring the role of psychological empowerment and power values. Hum. Relat. 2010, 63, 1743-1770. [CrossRef]

15. Dedahanov, A.T.; Lee, D.H.; Rhee, J.; Yoon, J. Entrepreneur's paternalistic leadership style and creativity. Manag. Decis. 2016, 54, 2310-2324. [CrossRef]

16. Khokhar, A.M.; Zia-ur-Rehman, M. Linking ethical leadership to employees' performance: Mediating role of organizational citizenship behavior and counterproductive work behavior. Pak. J. Commer. Soc. Sci. 2017, 11, $222-251$.

17. Kim, W.G.; McGinley, S.; Choi, H.-M.; Agmapisarn, C. Hotels' environmental leadership and employees' organizational citizenship behavior. Int. J. Hosp. Manag. 2020, 87, 102375. [CrossRef]

18. Ahmad, N.; Scholz, M.; Arshad, M.Z.; Jafri, S.K.A.; Sabir, R.I.; Khan, W.A.; Han, H. The inter-relation of corporate social responsibility at employee level, servant leadership, and innovative work behavior in the time of crisis from the healthcare sector of pakistan. Int. J. Environ. Res. Public Health 2021, 18, 4608. [CrossRef] [PubMed]

19. Afsar, B.; Cheema, S.; Javed, F. Activating employee's pro-environmental behaviors: The role of CSR, organizational identification, and environmentally specific servant leadership. Corp. Soc. Responsab. Environ. Manag. 2018, 25, 904-911. [CrossRef]

20. Cho, S.J.; Chung, C.Y.; Young, J. Study on the Relationship between CSR and Financial Performance. Sustainability 2019, 11, 343. [CrossRef]

21. González-Rodríguez, M.R.; Martín-Samper, R.C.; Köseoglu, M.A.; Okumus, F. Hotels' corporate social responsibility practices, organizational culture, firm reputation, and performance. J. Sustain. Tour. 2019, 27, 398-419. [CrossRef]

22. Hou, C.-E.; Lu, W.-M.; Hung, S.-W. Does CSR matter? Influence of corporate social responsibility on corporate performance in the creative industry. Ann. Oper. Res. 2019, 278, 255-279. [CrossRef]

23. Lin, Y.-E.; Li, Y.-W.; Cheng, T.Y.; Lam, K. Corporate social responsibility and investment efficiency: Does business strategy matter? Int. Rev. Financ. Anal. 2021, 73, 101585. [CrossRef]

24. Gutiérrez-Fernández, M.; Fernández-Torres, Y. Does gender diversity influence business efficiency? An analysis from the social perspective of CSR. Sustainability 2020, 12, 3865. [CrossRef]

25. Agarwal, J.; Stackhouse, M.; Osiyevskyy, O. I love that company: Look how ethical, prominent, and efficacious it is-A triadic organizational reputation (TOR) Scale. J. Bus. Ethics 2018, 153, 889-910. [CrossRef]

26. Rasheed, A.; Aslam, H.; Rashid, K. Antecedents of pro-environmental behavior of supply chain managers: An empirical study. Manag. Environ. Qual. Int. J. 2021, 32, 420-435. [CrossRef]

27. Donaldson, L.; Davis, J.H. Stewardship theory or agency theory: CEO governance and shareholder returns. Aust. J. Manag. 1991, 16, 49-64. [CrossRef]

28. Davis, J.H.; Schoorman, F.D.; Donaldson, L. Toward a stewardship theory of management. In Business Ethics and Strategy; Routledge: Milton Park, UK, 2018; pp. 473-500.

29. Wasserman, N. Stewards, agents, and the founder discount: Executive compensation in new ventures. Acad. Manag. J. 2006, 49, 960-976. [CrossRef]

30. Hernandez, M. Promoting stewardship behavior in organizations: A leadership model. J. Bus. Ethics 2008, 80, 121-128. [CrossRef]

31. Larbi, M. Environmental Stewardship and Corporate Social Responsibility: Implication for Consumers' Resistance to Negative Information. The Case of Apple in China; Beijing Normal University (BNU)—School of Normal Social Development: Beijin, China, 2014. [CrossRef]

32. Kuttner, M.; Feldbauer-Durstmüller, B.; Mitter, C. Corporate social responsibility in Austrian family firms: Socioemotional wealth and stewardship insights from a qualitative approach. J. Fam. Bus. Manag. 2021, 11, 238-253. [CrossRef]

33. Balakrishnan, J.; Malhotra, A.; Falkenberg, L. Multi-level corporate responsibility: A comparison of Gandhi's trusteeship with stakeholder and stewardship frameworks. J. Bus. Ethics 2017, 141, 133-150. [CrossRef]

34. AlSuwaidi, M.; Eid, R.; Agag, G. Understanding the link between CSR and employee green behaviour. J. Hosp. Tour. Manag. 2021, 46, 50-61. [CrossRef]

35. Kollmuss, A.; Agyeman, J. Mind the gap: Why do people act environmentally and what are the barriers to pro-environmental behavior? Environ. Edu. Res. 2002, 8, 239-260. [CrossRef]

36. Raza, A.; Farrukh, M.; Iqbal, M.K.; Farhan, M.; Wu, Y. Corporate social responsibility and employees' voluntary pro-environmental behavior: The role of organizational pride and employee engagement. Corp. Soc. Responsab. Environ. Manag. 2021, 28, 1104-1116. [CrossRef]

37. Islam, T.; Ali, G.; Asad, H. Environmental CSR and pro-environmental behaviors to reduce environmental dilapidation. Manag. Res. Rev. 2019, 42, 332-351. [CrossRef]

38. Ahmad, N.; Ullah, Z.; Arshad, M.Z.; waqas Kamran, H.; Scholz, M.; Han, H. Relationship between corporate social responsibility at the micro-level and environmental performance: The mediating role of employee pro-environmental behavior and the moderating role of gender. Sustain. Prod. Consum. 2021, 27, 1138-1148. [CrossRef] 
39. Abdelmotaleb, M.; Mohamed Metwally, A.B.E.; Saha, S.K. Exploring the impact of being perceived as a socially responsible organization on employee creativity. Manag. Decis. 2018, 56, 2325-2340. [CrossRef]

40. Chaudhary, R.; Akhouri, A. CSR perceptions and employee creativity: Examining serial mediation effects of meaningfulness and work engagement. Soc. Res. J. 2019, 15, 61-74. [CrossRef]

41. Yu, H.; Shabbir, M.S.; Ahmad, N.; Ariza-Montes, A.; Vega-Muñoz, A.; Han, H.; Scholz, M.; Sial, M.S. A contemporary issue of micro-foundation of CSR, employee pro-environmental behavior, and environmental performance toward energy saving, carbon emission reduction, and recycling. Int. J. Environ. Res. Public Health 2021, 18, 5380. [CrossRef]

42. Afsar, B.; Umrani, W.A. Corporate social responsibility and pro-environmental behavior at workplace: The role of moral reflectiveness, coworker advocacy, and environmental commitment. Corp. Soc. Responsab. Environ. Manag. 2020, 27, 109-125. [CrossRef]

43. Sendjaya, S.; Sarros, J.C. Servant leadership: Its origin, development, and application in organizations. J. Leadersh. Org. Stud. 2002, 9, 57-64. [CrossRef]

44. Bormann, K.C.; Backs, S.; Hoon, C. What makes nonfamily employees act as good stewards? Emotions and the moderating roles of stewardship culture and gender roles in family firms. Fam. Bus. Rev. 2020, 0894486520968826. [CrossRef]

45. Gandolfi, F.; Stone, S.; Deno, F. Servant leadership: An ancient style with 21st Century relevance. Rev. Int. Compar. Manag. 2017, $18,350-361$.

46. Faraz, N.A.; Ahmed, F.; Ying, M.; Mehmood, S.A. The interplay of green servant leadership, self-efficacy, and intrinsic motivation in predicting employees' pro-environmental behavior. Corp. Soc. Responsab. Environ. Manag. 2021, 28, 1171-1184. [CrossRef]

47. Oliver, B. Deconstructing CSR: Stewardship Theory. Available online: https://www.reutersevents.com/sustainability/ deconstructing-csr-stewardship-theory (accessed on 3 May 2021).

48. Bibi, A. Servant leadership and nurse's pro-environmental behavior: The role of autonomous and external motivations. Dinasti Int. J. Manag. Sci. 2020, 1, 785-801. [CrossRef]

49. Boga, I.; Ensari, N. The role of transformational leadership and organizational change on perceived organizational success. Psychol. Manag. J. 2009, 12, 235. [CrossRef]

50. Mastrangelo, A.R.; Eddy, E.J.; Lorenzet, S. The relationship between enduring leadership and organizational performance. Leadersh. Org. Dev. J. 2014, 35, 590-604. [CrossRef]

51. Chen, Y.-R.R.; Hung-Baesecke, C.-J.F. Examining the internal aspect of corporate social responsibility (CSR): Leader behavior and employee CSR participation. Commun. Res. Rep. 2014, 31, 210-220. [CrossRef]

52. Suganthi, L. Examining the relationship between corporate social responsibility, performance, employees' pro-environmental behavior at work with green practices as mediator. J. Clean. Prod. 2019, 232, 739-750. [CrossRef]

53. Rehman, A.; Ullah, I.; Ullah, Z.; Zeeshan, M.; Hussain, A.; Rahman, H.U. Adoption of green banking practices and environmental performance in Pakistan: A demonstration of structural equation modelling. Environ. Dev. Sustain. 2021, 1-21. [CrossRef]

54. Sun, H.; Rabbani, M.R.; Ahmad, N.; Sial, M.S.; Cheng, G.; Zia-Ud-Din, M.; Fu, Q. CSR, Co-Creation and green consumer loyalty: Are green banking initiatives important? A moderated mediation approach from an emerging economy. Sustainability 2020, 12, 10688. [CrossRef]

55. GermanWatch. Global Climate Risk Index 2020. Available online: https:/ / www.germanwatch.org/ (accessed on 2 October 2020).

56. The News. Islamic Banks' Market Share Up. Available online: https://www.thenews.com.pk/print/746679-islamic-banksmarket-share-up\#: \{\}:text=The\%20market $\% 20$ share $\% 20$ of $\% 20$ Islamic $\% 20$ banks $\backslash$ T1 $\backslash$ textquoteright $\% 20$ assets $\% 20$ stood $\% 20$ at $\%$ 2015.3,2020\%2C\%20primarily\%20due\%20to\%20investments (accessed on 28 April 2021).

57. Jafri, R. A Panoramic View of Pakistan's Banking System. Available online: https:/ /www.globalvillagespace.com/a-panoramicview-of-pakistans-banking-system/ (accessed on 14 March 2021).

58. NBP. CSR Initiatives. Available online: https://www.nbp.com.pk/csr/index.aspx (accessed on 24 July 2021).

59. ABL. Community Services. Available online: https://www.abl.com/the-bank/community-services/ (accessed on 24 July 2021 ).

60. UBL. Corporate Social Responsibility Initiatives. Available online: https://www.ubldigital.com/About-UBL/Sustainability/ CSR-Initiatives (accessed on 24 July 2021).

61. MCB. Corporate Social Responsibility. Available online: https://www.mcb.com.pk/investor-relations/corporate-socialresponsibility (accessed on 24 July 2021).

62. IQAir. Air Quality in Pakistan. Available online: https://www.iqair.com/us / pakistan (accessed on 9 May 2021).

63. Hyman, L.; Lamb, J.; Bulmer, M. The use of pre-existing survey questions: Implications for data quality. In Proceedings of the European Conference on Quality in Survey Statistics, Cardiff, UK, 24-26 April 2006; pp. 1-8.

64. Turker, D. Measuring corporate social responsibility: A scale development study. J. Bus. Ethics 2009, 85, 411-427. [CrossRef]

65. Tian, Q.; Robertson, J.L. How and when does perceived CSR affect employees' engagement in voluntary pro-environmental behavior? J. Bus. Ethics 2019, 155, 399-412. [CrossRef]

66. Liden, R.C.; Wayne, S.J.; Meuser, J.D.; Hu, J.; Wu, J.; Liao, C. Servant leadership: Validation of a short form of the SL-28. Leadersh. Q. 2015, 26, 254-269. [CrossRef]

67. Opoku, M.A.; Choi, S.B.; Kang, S.-W. Servant leadership and innovative behaviour: An empirical analysis of Ghana's manufacturing sector. Sustainability 2019, 11, 6273. [CrossRef]

68. Mithani, M.A. Innovation and CSR-Do they go well together? Long Range Plan. 2017, 50, 699-711. [CrossRef] 
69. Podsakoff, P.M.; Organ, D.W. Self-reports in organizational research: Problems and prospects. J. Manag. 1986, 12, 531-544. [CrossRef]

70. Fornell, C.; Larcker, D.F. Evaluating structural equation models with unobservable variables and measurement error. J. Market. Res. 1981, 18, 39-50. [CrossRef]

71. Gefen, D.; Straub, D.; Boudreau, M.-C. Structural equation modeling and regression: Guidelines for research practice. Commun Assoc. Inf. Syst. 2000, 4, 7. [CrossRef]

72. Hair, J.; Anderson, R.; Babin, B.; Black, W. Multivariate Data Analysis: A Global Perspective; Pearson: Upper Saddle River, NJ, USA, 2010.

73. Richter, N.F.; Schubring, S.; Hauff, S.; Ringle, C.M.; Sarstedt, M. When predictors of outcomes are necessary: Guidelines for the combined use of PLS-SEM and NCA. Ind. Manag. Data Syst. 2020, 120, 2243-2267. [CrossRef]

74. Matthews, L. Applying multigroup analysis in PLS-SEM: A step-by-step process. In Partial Least Squares Path Modeling; Springer: Berlin/Heidelberg, Germany, 2017; pp. 219-243.

75. Thakkar, J.J. Applications of structural equation modelling with AMOS 21, IBM SPSS. In Structural Equation Modelling; Springer: Berlin/Heidelberg, Germany, 2020; pp. 35-89.

76. Hameed, Z.; Khan, I.U.; Islam, T.; Sheikh, Z.; Khan, S.U. Corporate social responsibility and employee pro-environmental behaviors. South Asian J. Bus. Stud. 2019, 8, 246-265. [CrossRef]

77. García-Morales, V.J.; Jiménez-Barrionuevo, M.M.; Gutiérrez-Gutiérrez, L. Transformational leadership influence on organizational performance through organizational learning and innovation. J. Bus. Res. 2012, 65, 1040-1050. [CrossRef]

78. Samad, S. The influence of innovation and transformational leadership on organizational performance. Proc. Soc. Behav. Sci. 2012, 57, 486-493. [CrossRef]

79. Hsieh, J.Y.; Liou, K.T. Collaborative leadership and organizational performance: Assessing the structural relation in a public service agency. Rev. Public Pers. Admin. 2018, 38, 83-109. [CrossRef]

80. Choudhary, A.I.; Akhtar, S.A.; Zaheer, A. Impact of transformational and servant leadership on organizational performance: A comparative analysis. J. Bus. Ethics 2013, 116, 433-440. [CrossRef]

81. Donia, M.B.; Raja, U.; Panaccio, A.; Wang, Z. Servant leadership and employee outcomes: The moderating role of subordinates motives. Eur. J. Work Org. Psychol. 2016, 25, 722-734. [CrossRef]

82. Ozyilmaz, A.; Cicek, S.S. How does servant leadership affect employee attitudes, behaviors, and psychological climates in a for-profit organizational context. J. Manag. Org. 2015, 21, 263-290. [CrossRef]

83. Barauskaite, G.; Streimikiene, D. Corporate social responsibility and financial performance of companies: The puzzle of concepts, definitions and assessment methods. Corp. Soc. Responsab. Environ. Manag. 2020, 28, 278-287. [CrossRef]

84. Belu, C.; Manescu, C. Strategic corporate social responsibility and economic performance. Appl. Econ. 2013, 45, 2751-2764. [CrossRef]

85. Olowokudejo, F.; Aduloju, S.A.; Oke, S.A. Corporate social responsibility and organizational effectiveness of insurance companies in Nigeria. J. Risk Financ. 2011, 12, 156-167. [CrossRef]

86. Anthony Wong, I.; Hong Gao, J. Exploring the direct and indirect effects of CSR on organizational commitment. Int. J. Contemp. Hosp. Manag. 2014, 26, 500-525. [CrossRef] 